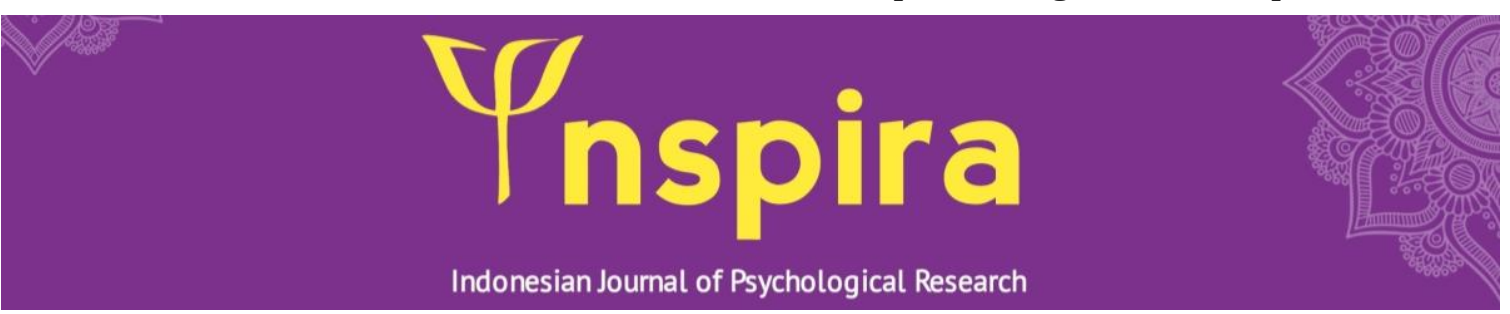

\title{
Peers and sources of information and their implications for adolescent sexual behavior
}

Khairil Fauzan K.凶

Department of Environmental Health, Sekolah Tinggi Ilmu Kesehatan Bustanul Ulum, Aceh, Indonesia

\section{${ }^{凶}$ Corresponding author: \\ Khairil Fauzan K (email: fauni_ozan@yahoo.com)}

\section{Article History:}

Received: January 6, 2020

Revised: February 8, 2020

Accepted: March 8, 2020

Published: June 18, 2020

\section{Keyword:}

adolescents; peers; sexual behavior; sources of information

How to cite (APA $7^{\text {th }}$ Edition)

Fauzan K., K. (2020). Peers and sources of information and their implications for adolescent sexual behavior. INSPIRA: Indonesian Journal of Psychological Research, 1(1), 25-29. https://doi.org/10.32505/inspira.v1i1.1721 


\section{INTRODUCTION}

Adolescence is transition phase from childhood to adulthood. Santrock (2010) stated in adolescence, individual changes and development include emotional, cognitive, moral, social and physiological aspects occur concurrently. Kusmiran (2011) proposed that one important aspect of transformations that must be focused is physiological changes which an important period when the occurrence of the first menstruation called menarche in women, while in men is marked by wet dreams. Since the body will experience dramatic changes because the body begins to produce sexual hormones which affect the reproductive system.

In line with the changes that occur in adolescents, they also challenged with tasks that are different from those in childhood period. As is known, in every developmental phase, including adolescence, individuals have developmental assignments that must be accomplished (Santrock, 2010). Unfortunately, not all adolescents can accomplish these tasks completely since adolescence is said to be a problematic period where adolescents also encountered with variety of problems. One problem emerges among adolescents is problem around sexuality, such as Human Immuno Deficiency Virus (HIV) and Acquired Immune Deficiency Syndrome (AIDS) as well as Narcotics and Other Addictive Substances (Drugs)(BKKBN, 2012).

Additionally, information about sexual problems should begin to be given during adolescents, thus they do not obtain information from other people or from unreliable and invalid sources. Providing information on sexual problems becomes even more important considering that adolescents are in an active sexual potential, because it is related to sex drive that is influenced by hormones. However, they often have insufficient information related to sexual activity which can be dangerous for the mental development of a teenager. Moreover, Haryanto (2012) stated that most adolescents do not know the impact of their sexual behavior, often adolescents are not mature enough to have sexual intercourse, especially if they have to bear the risks of sexual intercourse.

According to Pieter (2010) youths spend a lot of time outside the home and with friends. This condition makes adolescents vulnerable to the influence of their friends in choosing their interests, attitudes and behaviors. The most prominent change based on peer influence is the change in heterosexual relationships in which adolescents like the opposite sex. A study among high school student (2015) found that the factors that influenced adolescents to have sexual intercourse were peers who had boyfriends and friends who agreed with premarital sex which encourage friends to do this behavior. Furthermore, based on initial interview with some adolescents and teachers revealed that some of students involved in premarital pregnancy and abortion. Thus, this study intended to analyzed factors that influence adolescents sexual behavior.

\section{RESEARCH METHOD}

The research design used was explanatory research with associative explanatory methods. This research was conducted in SMA Negeri 1 Kejuruan Muda. The participants of this study were 38 high school students that recruited using purposive sampling technique with the following criteria; first is third year students, second students who have been dating or currently in relationships and the last one is students who are willing to be research respondents. 


\section{RESULT}

Results revealed the influence of information factors and peer factors on adolescent sexual behavior. It was found that the percentage of adolescents exposed to information media was $60.5 \%$ and adolescents not exposed to information media was also 39.5\%. However, Based on the 38 adolescents studied, it was found that the majority of adolescents had a weak influence on their peers, namely $63.2 \%$, while the strong adolescents had a strong influence on their peers as much as $36.8 \%$. For sexual behaviors, based on table 4.3 of the 38 adolescents studied, it was found that adolescents who did sexual behavior were $47.4 \%$ and adolescents who did not do sexual behavior by $52.6 \%$

Based on the cross tabulation of information sources with adolescent sexual behavior (see Table 1.), it was found that adolescents who were exposed to information sources such as online media, print media and electronic media tended to perform sexual behavior by $47.4 \%$, while adolescents who were not exposed to information media showed no sexual behavior by as much as $47.4 \%$. $34.2 \%$. Based on the chi square test, it was found that $\mathrm{p}<0.05$, where there was a relationship between sources of information and adolescent sexual behavior.

Table 1 Crosstabs information sources with adolescent sexual behavior

\begin{tabular}{cccccccc}
\hline \multirow{2}{*}{$\begin{array}{c}\text { Information } \\
\text { Resources }\end{array}$} & \multicolumn{4}{c}{ Yexual Behavior } & \multirow{2}{*}{ Total } & \multirow{2}{*}{$p$ (Sig) } \\
\cline { 2 - 5 } & $\mathrm{f}$ & $\%$ & $\mathrm{f}$ & $\%$ & $\mathrm{~F}$ & $\%$ & \\
\hline $\begin{array}{c}\text { Strong } \\
\text { influence } \\
\text { Weak } \\
\text { influence }\end{array}$ & 18 & 47,4 & 5 & 13,1 & 23 & 60,5 & \\
\hline Total & 20 & 52.6 & 18 & 47.4 & 38 & 100 & 0.000 \\
\hline
\end{tabular}

Based on the cross tabulation of peer factors with adolescent sexual behavior (see Table 2.), it is found that adolescents who have strong relationships with their peers will have negative sexual behavior $(28.9 \%)$ while adolescents who have less strong relationships with their peers will not engage in sexual behavior (28.9\%). 39.4\%). Based on the chi square test, $\mathrm{p}(0.016)<0.05$ was obtained where there was a peer relationship with adolescent sexual behavior.

Table 2 Crosstabs peers with adolescent sexual behavior

\begin{tabular}{|c|c|c|c|c|c|c|c|}
\hline \multirow{3}{*}{ Peers } & \multicolumn{4}{|c|}{ Sexual Behavior } & \multirow{2}{*}{\multicolumn{2}{|c|}{ Total }} & \multirow{3}{*}{$p($ Sig $)$} \\
\hline & \multicolumn{2}{|c|}{ Yes } & \multicolumn{2}{|c|}{ No } & & & \\
\hline & $f$ & $\%$ & $f$ & $\%$ & $\mathrm{~F}$ & $\%$ & \\
\hline Strong & 9 & 23,7 & 15 & 39,4 & 24 & 63,2 & \multirow{2}{*}{0.016} \\
\hline Weak & 11 & 28,9 & 3 & 7,9 & 14 & 36,8 & \\
\hline Total & 20 & 52.6 & 18 & 47.4 & 38 & 100 & \\
\hline
\end{tabular}

From the three independent variables, namely the variable knowledge, information sources and peers, it was found that the variables that had a significant influence were the knowledge variable ( $\mathrm{p} 0.03$ ) and the information source variable (0.007) where both variables had a $\mathrm{p}$ value (Sig) $<0.05$. stated that this variable has a positive effect on the dependent variable, namely adolescent sexual behavior. 


\section{DISCUSSION}

Based on the results of the multivariate test using logistic regression test, it was obtained that the $\mathrm{p}$ value was $0.007<0.05$, thus it can be said that the variable information sources had a significant effect on adolescent sexual behavior.

This research is in line with previous research conducted by Suidhan (2010) regarding the Relationship between Reproductive Health Knowledge and Late Adolescent Sex Behavior in Health and Non-Health. The results of the study using multivariate analysis showed that the relationship between media exposure (Wald $=10.687, \mathrm{p}=0.001)$ was the dominant factor that led to premarital sex among students.

Sources of information are the availability of media that can be accessed by teenagers such as online media, electronic media and printed media. Adolescent sexual activity and behavior are also heavily influenced by technological advances, such as print and electronic media. Teenagers easily get pornographic things from magazines, television, vcd, and the internet, while teenagers tend to imitate or try new things in order to answer their curiosity. In line with this, research conducted in Bali (Denpasar and Singaraja), adolescents have sexual relations due to the desire to experiment because of stimulation from magazines, films, pornographic images of $(62.41 \%)$, friends $(33.69 \%)$, teachers $(14.18 \%)$, and parents $(11.7 \%)$.

Accordingly, the ease with which teenagers have in accessing various media nowadays makes teenagers vulnerable to sexual acts. For example, when watching movies in a cinema, it has become commonplace to see kissing scenes that can inspire young people watching to do the same thing as what they see. In addition, the existence of smartphones is a source of online information that has great potential for sexual exposure where adolescents can personally easily access it anytime and anywhere.

Based on the results of the multivariate test, it is known that there is no peer influence on sexual behavior. In this study, it means that peers do not determine adolescent sexual behavior. According to Santrock, conformity with peers during adolescence can be positive or negative. Generally, adolescents are involved in all forms of negative conformity behavior such as: using obscene language, stealing, destroying, and making fun of parents and teachers, following dating behavior. However, much of the peer conformity is positive and consists of a desire to be included in the peer world, such as dressing like friends and a desire to spend time with "gang" members. Such situations can also involve prosocial activities such as when raising money for meaningful purposes. During adolescence, especially early adolescence, adolescents follow peer standards more closely.

Thus, according to the researchers' assumptions, peers in this study are not an example and a social model for negative sexual behavior, this can be because there is still a sense of shame and reluctance towards fellow friends.

\section{CONCLUSION}

In conclusion, this current study found that there was significant effect of information resources on adolescents' sexual behavior while there was no significant effect of peers. Thus, adolescents are expected to filter accurate information about sexual behavior and educate 
themselves on sexual behavior so that they are not mistaken and are not trapped in unacceptable premarital sexual behavior.

\section{REFERENCES}

Badan Kependudukan dan Keluarga Berencana Nasional. (2012). Pengelolaan pusat informasi dan konseling remaja dan mahasiswa.

Darmayanti, D., Lestari, Y. \& Ramadani, M. (2011). Peran teman sebaya terhadap perilaku seksual pranikah siswa SLTA kota Bukit Tinggi. Jurnal Kesehatan Masyarakat Andalas 6(1), 24-27. https://doi.org/10.24893/jkma.v6i1.84

Hariyanto. (2012). Pendidikan seksual pada remaja. Retrived August 2018, from belajarpsikologi.com/pendidikan-seksual-pada-remaja/html

Kusmiran. (2011). Kesehatan reproduksi remaja dan wanita. Salemba Medika.

Pieter. (2010). Pengantar psikologi untuk kebidanan: Edisi Revisi. Prenada Media Group.

Ririn. (2009). Faktor yang mempengaruhi perilaku seks pranika pada remaja SMA di Surakarta. Retrived August 2018 from http://eprints.ums.ac.id/5959/

Santrock, J. W. (2010). Adolescence: Daurperkembangan hidup. Erlangga.

Tukiran. (2010). Keluarga berencana dan kesehatan reproduksi. Pusat Studi kependudukan dan Kebijakan Universitas Gajah Mada. 